\title{
Objective Communication of Indian Partition Violence and Trauma in Sadat Hasan Manto's Stories
}

\author{
Udaya Raj Paudel \\ Doctoral Candidate in English (Communication), Tribhuvan University, Kathmandu, Nepal \\ udayapaudel7@gmail.com
}

Published Date: October 11, 2018

\begin{abstract}
The violence and trauma of Indian partition changed the social and political course of the Indian subcontinents in such a way that its repercussions and ramifications are still palpable. Along with the number of death and the amount of destruction, the event left a deep psychological scar on the mind of millions of people in general and on the mind of women and children in particular. Such 'age of foolishness, the season of darkness and the time of despair' could leave no writers of the time and aftermath untouched. And so far the representation of Indian partition violence and trauma is concerned, whatever the cause and whoever the culprits accused or censured, most of the historians have done their best to silence violence by focusing on the great causes rather than the events themselves. The actual acts of abduction, uprooting, train raids, trauma, madness, suicide, murder and acts of destruction are vexed to keep under the carpet. Unlike this, Sadat Hasan Monto, one of the greatest Urdu writers, visualizes the unprecedented objectivity in the rendition of this heartrending milieu in his stories: "Toba Tek Singh," "Cold Meat", "Open It" ("Khol Do") and "The Dog of Titwal." Thus, methodologically, this paper makes content analysis of the purposively selected secondary resources where violence and trauma remain at the center rather than 'the politics of blame' on Muslims or Hindus as perpetrator of the consequence.
\end{abstract}

Keywords: Partition, Violence and Trauma, Content Analysis, Hindu, Muslim

\section{Conceptual And Contextual Background of THE STUdy}

The stroke of the midnight of August 14, 1947 is definitely the first of its kind in the modern history of human civilization that the people still get traumatized. The history of partition remains as the history of violence. There was human misery on a colossal scale all around and millions were left bereaved, destitute, homeless, hungry and thirsty. Worst of all, millions of the survivor-victims were desperately anxious and almost hopeless about their future. As the question emerges about the representation of violence, there are almost no writers who reach the acme of Manto's neutrality. His writings remain free from the prose of stereotyping, disparaging, or demonizing of the other community in terms of religion, culture, politics and nationality or any other identity markers.

Objectivity in his writing is achieved through different means. One is the adoption of the victim's point of view that completely erases the authorial voice, while reading the text. Manto neither makes any effort to describe characters in detail nor does he try to identify them in the name of religion, culture or any communal group is the other medium. His nostalgia for India, his estrangement with the Muslim elites in Pakistan and his perceived sympathy with the subaltern, no matter (whatever) they are as Hindus, Muslim or Sikhs, help him avoid the nationalist bias, which crops up here and there, time and again as a major flaw with some of the writers of his time. Though Manto became a second-class citizen overnight, he still kept on looking upon himself as a citizen of undivided India. In other words, his foundation of writing is based on the no man's land mocking at the irrationality and inhuman activity in relation to partition.

As the Partition took place, Manto's family migrated to Pakistan but Manto remained in Bombay for several months. He was thoroughly disturbed when he arrived in newly created country, Pakistan. Khalid Hassan aptly 
captures the situation as: "His early days in Pakistan were bewildering. Everything was out of joint. There was a mad stampede for allotments of evacuee properly and a sense of terrible insecurity. Some people were living as if there was going to be not tomorrow. Those who had been once rich were on the streets" (qtd. in Alter 96). He was much shocked because of the cultural chasm created by the split of India into two nations. These confusing days had affected his writing quite radically but from the perspective of subaltern. He captured as "...purely and inexplicably the return of the event against the will of the one it inhabits" (Caruth 3, "Traumatic Awakenings"). He started writing with a new vigor in an ironic strand. He remained opposed to partition and considered it to be an absurd, irrational and brutal human activity. He wrote related stories from the victim's point of view by recreating the trauma suffered by the innumerable identified and unidentified ones. Yale Professor Geoffrey Hartman observes something very contemporary about the deep psychological scar in the people that "... violence is coming ever nearer, like a storm- a storm that may have already moved into the core of our being" (552). Similarly, Manto mirrors the history of partition as the history of dislocation, separation, riot, rape, arson, absurdity, madness, communal hatred, religious intolerance, loss of identities and what not (?).

\section{Impartial Representation of Indian PARTition Violence in "Toba Tek Singh"}

"Toba Tek Singh" presents the trauma of the millions dislocated on both sides of the border through lunatic Bishan Singh's point of view. "Open It" textualizes the trauma of raped women from the perspective of Sakina, a repeatedly raped seventeen years old Muslim girl by the Muslim volunteers themselves. In "It Happened in 1919," Thaila, an innocent person, is killed by the British and after two days his sisters, Shamshad and Almas, were invited to dance in the imperial presence and shot dead after the dance. A Sikh, Ishar Singh, in "Cold Meat" rapes a Muslim girl who was already cold (dead) and carries the trauma of guilt and repentance in his later life. "The Women in the Red Raincoat" visualizes the theme of rape and a nightmare landscape of random violence as common affair during the time of partition. Likewise, Hindu rioters abduct a Muslim girl in "Xuda Ki Kasam." we also find Manto's rapist characters to be Hindu, Sikhs and Muslims. And his victims are also from both: Indians and Pakistans. Hence, he takes no sides and writes neither as a Hindustani nor as a Pakistani. In short, these stories give us the impression of the monstrosity of the violent time and milieu devoid of any preconceived social, political, cultural, religious and national identities.

"Toba Tek Singh" exposes Monto's ability of awakening the deep slumbered humanity. He makes excellent presentation of his work by imparting the shocking effects of violence in readers by forcing them to vicariously visualize the scenes in their minds. His readers are compelled to undergo a deep thinking because of the fragments in his writing and in the process of filling the gap they come to internalize the horrific violence they had created. Hence he does not commit the pitfall as the other writers of the time usually did by narrativizing the events of violence. Monto through "Toba Tek Singh" makes us feel the transforming effects when Bishan Singh frequently talks about his native place Toba Tek Singh "Uper the gurgur the annexe di bay dhiana di mung di daal of Toba Tek Singh and Pakistan"(148). The division of the country had become utterly confusing. Both mad and partially mad like Bishan Singh were unable to decide whether they were in India or newly heard and formed nation, Pakistan. Those who read "Toba Tek Singh" are forced to identify themselves with the traumatized victim as Bishan Singh's trauma is transferred implicitly to the readers. Moreover, Bishan Singh's death in no man's land inculcates the greater empathy to the victims of the time than the other aspects of the novel.

"Several officials rushed to the spot and found that the man, who has remained on his legs, day and night for fifteen years, was now lying on his face. Over here, behind identical wires, lay Pakistan. In between, on a bit of land that had no name, lay Toba Tek Singh. (Manto, Freedom 148)

When Bishan Singh dies, he dies in no man's land, which makes readers feel anxious. At the time of his death "ear splitting cry," "had remained," "lay Toba Tek Singh" and "a bit of land that had no name" visualizes the pathetic death of millions like Toba Tek Singh. Manto also rotates the mental impression of the story to the readers through the alteration of laughter and cry time and again. But 'shock effect' plays the vital role in the readers when Monto ends the story with Bishan Singh's tragic and pathetic end/death. 
Monto succeeds in inculcating human values in readers by making the strong flashes of the partition period. He easily succeeds in imparting the shocking effects when the reader finds the protagonist himself as the agent of the going on violence in "Cold Meat." The powerful art/ craft is seen in the work of Manto when he makes readers like us share the pain that the protagonist, Ishar Singh, is undergoing because of his heinous act of having a violent sexual intercourse with the neat dead body of an elegant Muslim girl. Manto begins with light humour and suspense but teases, ridicules and humiliates till the reader terminates reading or listening. In other words, reader generates hate in himself/herself when his/her inner feelings are poked up once again. Though there is narrative, the objectivity is there. After this disgusting activity Ishar Singh is traumatized and there is emotional gap in his later female partner. Ishan Sing is also a character who involves in looting, rape and murder. As he kills six persons, carries a beautiful lady and undertakes a violent copulation with her, a moment of epiphany takes place when he discovers his intercourse with the cold body and hence after he starts a strong and persistent hatred on himself in particular and all humanity in general. The story is in flashback. His trauma is similar to the trauma of Coleridge because of colonial violence expressed in "Ancient Mariener." So Manto makes readers go under penance but it results in positive note because it at least intends a social reform. The story revolves around sexual psychology with a subtle message that how cruel are human beings even at the time of violence. Manto's sympathy lies with subaltern characters and mostly on females that has an amazing capacity of captivating the readers. However, since Manto is neither a didactic nor a sentimental writer, he never writes with the goal of appealing to the emotion of the readers rather his readers are constantly captured by the sequential development of the events with a beautiful recreation of violence and trauma in both fragmented and shrewd weaving of the plot.

\section{NeUtral Depiction of Violence and Trauma in "Khol Do"}

Likewise, "Khol Do" ("Open It") depicts 'the theme of partition' more powerfully. It is a story about an old man's attempt to find out his only daughter named Sakina who is missed while escaping the looters and rapists. When Old Sirajuddin, Sakina's father, comes in consciousness, he starts searching his daughter. He makes plead to the Pakistani volunteers to help him search his daughter and they gave the words that they would leave no stone unturned to find her. After ten days, Sakina is found in unconscious state of mind on the roadside. She is brought inside the hospital and as the doctor turns on the light then the traumatized father recognizes his daughter and his heart leaps no bounds but when doctor finds the room rather suffocating and utters 'open it' then doctor himself becomes traumatized breaking into cold sweat. The reason is that the doctor had asked to open the window but the body of Sakina "stirred slightly on the stretcher [and] the lifeless hands untied the waistband" (Manto, Freedom 134). It is because the ones, who were appointed to rescue the victims of partition, even across the boarder, repeatedly raped her. It was unbelievable that volunteers would be rapists. In such traumatic face of partition theme, Manto creates the climax of the story in his dramatic presentation by scooping Sakina as a rape victim who remained unable to distinguish the different commands made by different people in different situations and is unconsciously used to presenting herself for violent and mass intercourse. Ian Talbot expresses similar views when he "explores the human dimension of partition through the physical and psychological impact of the four experiences of violence, abduction, migration and resettlement" ("Human Drama" 229). The human dimension of the partition violence is what remains neglected in textbook histories of India and Pakistan.

\section{OBjective Illustration of Violence in "The Dog OF Titwal”}

"The Dog of Titwal" is also a story with the strong feelings of national boundaries and national identities based on similar theme of partition. The story is set in a geographical space called 'Titwal.' The dog makes its first appearance on the scene by shattering the melancholic mood by its bark. The dog is a figure of innocence but both sides try to affix the identity. The dog is given food but snatched and named Jhun Jhun in Indian side. And 
when the same dog moves to Pakistan then it is named Shun Shun. Meanwhile it is shot dead first by Indian and second by Pakistani soldiers. They try to make it of their respective nation by giving the different names in the tags but the identity of the dog is questioned and suspected in both sides as a spy. Similarly, the ordinary people were tormented and disturbed because of the remorseless milieu created due to the separation of the country. The symbolic representation of the dog deals with the identity crisis of the common people. The journey of dog that it makes from India to Pakistan and vice-versa suggests the quest of identity in the time of partition. But the dog instead of getting the identity gets hot bullet suggests that the condition of people during partition was like of this dog in terms of identity, basic human rights and justice.

Manto maintains objective representation by setting the camps of Indian and Pakistani army at the same height, and involvement of both sides in killing the dog. Through the suffering of an animal, Manto makes his readers remind the people being homeless with immense suffering during the time of partition. Human condition was the condition of a stray dog roaming and searching for food, and even security. Millions of such people met their tragic end like the dog caught in crossfire between the Indian and Pakistani armies. Based on religion and national geographic boundaries, soldiers started fighting in the name of respective nations. Manto mocks at the gullibility and mindlessness of the people during the time of war. The story not only allegorizes the predicament of the uprooted and exiled people but also commented on the dehumanization like war, which fostered irreconcilable mutual hatreds. Without sparing either of the two sides, Manto represents the breakdown of trust; the atmosphere of suspicion and paranoia, the hostility and rigidity of thought that percolate down even to the common man. Manto mocks ironically not only the atmosphere of hostility and suspicion but also very skillfully shows the absurdity of the situation. The partition of the country deeply pained him. The pain never allowed him to experience the pleasure of being free from the brutal British Raj. For him, the end of British Raj was not an occasion for celebration but that of mourning. He always talked about the breakdown of a civilization into mutually hostile and warring nation states. Manto's spotlight falls on the human tragedy of partition engendered by black antagonism arising from the divisive politics of the 1940s.

Manto does not suffer from the tendency of preconceived identity markers like religion, class, nationality and so on. He does not stereotype Hindus or Muslims or Sikhs on any basis. He neither deifies nor demonizes any community of the country. For him, at the time of spiritual crisis, any man, irrespective of caste, creed, religion or nationality could be as irrational and inhuman as his characters. He describes the acts and scenes of communal violence with out taking sides. Manto's writing encapsulates his sympathy for the underdogs. Manto's representation of the partition violence pinches the intellect rather than appeal to the emotion. It is highly realistic and achieves remarkable objectivity, for it neither shows any biased ness for contending nationalisms of the traumatic times, nor hid own socialism or specific cultural visibility, nor any geographical, political or religious markers. It does not either present detailed characterization or grant the narrator hid authorial voice. His works are remarkably neutral with the employment of the victim's point of view and are free from the ideological othering, which crops up here and there, time and again in even some of the renowned writers of south Asian partition literature.

Manto has maintained the specificity of the rampant violence. Manto records his experience of partition violence and Hindu -Muslim riot realistically in a cool, detached manner using minimum of words but all the same powerfully shocking and shaking the readers and thereby transforming them into the world of partition. His stories recreate the trauma of all those people. Though he was a sympathizer with the subalterns and a man of Leftist leanings, Manto remained safe on objective representation of partition violence. He opens a new perspective of revisiting past. His works of fiction challenge the disciplinary history perpetuated from the distant past.

The traditional historiography that represents a society in a normalized and homogenized way with all its social texture smoothed, its local specificity subordinated and its documentary evidence submerged by paraphrase for the sake of a coherent narratable and teleological plot. In the name of nationality and progress, national 
histories of Hegelian model try their best to neglect heterogeneity of a society and the lived experiences of its general public. Indian history even in the most dedicated hands remains mimicry of certain modern subject of European history and is bound to represent a sad figure of lack and failure. Even after the independence of India, Indian historiography is filled with a double bind where historians repudiate the colonizer's construction of Indian people and India and yet follow the colonialist model of history. The official or academic histories of the subcontinents remain mimicry of European historiography that discourages representation of violence, heterogeneity of a society and the painful stories of individuals in the name of rationality, progress and objectivity. Sadat Hassan Manto tries to recreate an encompassing history through the excavation of unexplored events to be encompassed in the process of writing history.

National histories of both India and Pakistan hide the religiously motivated upheavals of 1947 as irretrievable other in relation to the organs of political rationality and progress. And it is the work of Sadat Hassan Manto that endeavors to recreate the violence torn nation. Since no community of individual would like to represent itself as violent and hence uncivilized, official histories shy away from a frank discussion of the history of rape, abduction and killing, and the state sponsored drive that followed to evict aliens and recover nationals that remain irreversible of their wishes. Reasons behind obliterating violence are various. Nevertheless, the professed motive can be to secure the peaceful coexistence of different peoples.

Attempts to erase violence from history and by extension memory directly emanates from the centrality of state in the project of writing history. In the hierarchy of violence, only the violence perpetrated by state is generally perceived as rational and purposeful. Violence can be created and organized in various ways. One of the kinds relates to the violence in its raw and unorganized form where people become victims of violence at a moment of loss of sanity and suspension of judgment. This is the violence witnessed at Partition and should be forgotten in the best interest of the social harmony and normal everyday life. Any mentioning let alone institutionalization of it is detrimental to the project of nationalism, progress, and rationality.

Detailed representation of violence and its analysis has never been a subject of honest and frank analysis since it is an ongoing and ever present threat in present-day India. Unlike the German historiography of the Holocaust that was primarily necessitated by the question of guilt and the need to remember the suffering, Indian historiography makes every attempt to obliterate the violence so as to preserve what is singularly unique about India, its unity in diversity. And it is quite significant to note here that while it is possible to discuss and debate the Holocaust as a distant event, Partition violence should be left over to follow its course, out of memory and out of history in the best interest of all. However, this intense harping on unity in diversity seems to collapse then even after fifty years Babari Masjid, Godhara, and many others seem to become a rule rather than an exception. The patronizing move of presenting selective facts of history to its general public is symptomatic of the colonial mentality.

Disciplinary or textual historians try not to inflict violence in a relatively peaceful society; it is a social irresponsibility of historians. In the similar way, historian's history plays politics to assign violence to the other of a society- uneducated, marginal and subalterns. So, nationalist historiography gives almost a worshipful attention to the representation of elites, who are always praised for their role in the independence of India. Another reason for keeping violence in the shadow of nationhood is the Hegelian model of history. For Hegel state is the main controlling agent of violent people assures civilization. At the same time state equates history and again history is a process of freedom, freedom is possible only in the state. For Hegel, the story of individuals alone is not yet history. Therefore, as partition historiography is influenced by Hegelian history. It is this model of history that treats state-sponsored violence as unfortunate but historical and legitimate and the violence by people as ahistorical and aberration. Equating history with civilization, peace progress and modernity historian's history treats violence as civilization's other, for the civilization is taken as a state of non violence where adult human beings negotiate with one another and determine their rights and duties through rational argument not through murder, abduction and rape. (Pandey, "Remembering", 54) 


\section{CONCLUSION}

Thus, to keep violence under the shadow of independence and nationhood, Indian official histories make certain strategic moves. The happenings that accompanied partition are sidelined as if they were not the events of the time. The actual acts of abduction, rape, uprooting, train raids, trauma, madness, suicide, murder and other acts of destruction are kept under the carpet in the teleological mode of history. Thus, the works of Sadat Hassan Manto are not only the examples of objective representation of violence but also a significant part of history. Glorification of independence in the history, therefore, has to be accompanied by a detailed description of massive violence, inhuman acts, cruelty and brutality. The works of Manto remain as the testimonials of violence during the partition and reveal that the state sponsored history is incomplete. Hence, his works of prose are free of stereotyping, disparaging or demonizing of the other community in terms of religion, culture, politics and nationality. Objectivity in his writing is achieved in various ways: he does not assert the authorial voice, he does not describe character in detail, he writes from no man's setting, his theme is partition violence, he avoids nationalist favoritism and he does not presuppose any other identity markers. Thus his works of partition recreate the horror, terror, trauma, murder, rape, abduction, loot and suicide of the hungry, thirsty and destitute victims of partition in an unprecedented objective manner.

\section{REFERENCES}

1. Alter, Stephen. "Madness and Partition: The Short Stories of Saadat Hansan Manto." Alif: Journal of Comparative Poetics 14(1994): 91-100.

2. Manto, Saadat Hasan. For Freedom's Sake: Selected Stories and Sketches, Saadat Hasan Manto. Ed. Muhammad Asaduddin. Trans. Muhammad Asaduddin. Karachi: OUP, 2001. 112-148.

3. "The Dog of Titwal". The Story and its Writer: An Introduction to Short Fiction . Ed. Ann Charters . Boston: Bedford, 1995. 883-886.

4. "Mozel." Stories About the Partition of India. Ed. Alok Bhalla. Trans. Tahira Naqvi. New Delhi: Harper Collins, 1994.153-172.

5. "Toba Tek Singh," The Story and its Writer: An Introduction to Short Fiction . Ed. Ann Charters . Boston: Bedford, 1995.

6. Pandey, Gyanendra. Remembering Partition: Violence, Nationalism and History in India. Cambridge: CUP, 2001.

7. "The Prose of Otherness." Subaltern Studies VIII: Essays in honour of Ranjit Guha. Eds. David Arnold and David Hardiman. New Delhi: OUP, 1994. 188-221.

8. Talbot, Ian. "Literature and the Human Drama of the 1947 Partition." Region and Partition: Bengal, Punjab and the Partition of the Subcontinent. Ed. Ian Talbot and Gurharpal Singh. Karachi: OUP, 1999. 228-268.

Citation: Udaya Raj Paudel. "Objective Communication of Indian Partition Violence and Trauma in Sadat Hasan Manto's Stories". American Research Journal of Humanities and Social Sciences, vol 4, no. 1, 2018, pp. 1-6.

Copyright (c) 2018 Udaya Raj Paudel. This is an open access article distributed under the Creative Commons Attribution License, which permits unrestricted use, distribution, and reproduction in any medium, provided the original work is properly cited. 